\title{
Synthesis of Magnolignan, a New Pigment Lightening Component, via a Suzuki-Miyaura Reaction
}

\author{
Shuhei Narita, Tetsuhiro Ogura, and Toyonobu Usuki \\ Department of Materials and Life Sciences, Faculty of Science and Technology, Sophia University, 7-1 Kioicho, Chiyoda-ku, \\ Tokyo 102-8554, Japan \\ Correspondence should be addressed to Toyonobu Usuki; t-usuki@sophia.ac.jp
}

Received 25 April 2012; Revised 10 July 2012; Accepted 10 July 2012

Academic Editor: Lorenzo Cerretani

Copyright (C) 2013 Shuhei Narita et al. This is an open access article distributed under the Creative Commons Attribution License, which permits unrestricted use, distribution, and reproduction in any medium, provided the original work is properly cited.

Magnolignan, 2,2' -dihydroxy-5, $5^{\prime}$-dipropyl-biphenyl (1), is a down-regulator of melanin synthesis that inhibits the maturation of tyrosinase. In this study, a concise total synthesis of 1 was achieved in five steps with $50 \%$ overall yield starting from commercially available trans-anethole (2) via a Suzuki-Miyaura reaction.

\section{Introduction}

Various treatments with melanin synthesis inhibitors, lasers, and chemical peels have been investigated to achieve lightening effects for pigmented skin in the field of cosmetics. In particular, melanin synthesis inhibitors, such as hydroquinone, have been shown to be an effective treatment of melasma and a prophylactic agent for hyperpigmentation [1]. Melanin synthesis inhibitors have been widely used as lightening components in cosmetic formulations. While hydroquinone has a remarkable lightening effect, its strong bleaching action causes skin irritation. Therefore, alternative hydroquinone derivatives that have a mild or nonirritating effect have been investigated.

Researchers at Kanebo Cosmetics Co. Ltd., Japan, have proved that compounds with a biphenol framework are extraordinarily effective as melanin synthesis inhibitors [2]. Structure-activity relationship (SAR) studies of biphenol compounds strongly suggested that 2,2'-dihydroxy-5, $5^{\prime}$ dipropyl-biphenyl (1, Figure 1), also known as magnolignan or tetrahydromagnolol, has a greater lightening effect than the natural products magnolol and honokiol, which are isolated from the bark of Magnolia officinalis or M. obovata [3]. The lightening effect of magnolignan 1 was validated by several bioassays, such as the de novo melanin synthesis [4], the tyrosine hydroxylase assay [5], and melanin measurements [6]. For these studies, the new lightening compound $\mathbf{1}$ was synthesized using the oxidative coupling method previously reported by Sartori and co-workers [7]. Here, in this paper, a concise total synthesis of magnolignan $\mathbf{1}$ is described. The key step in the synthesis is a Suzuki-Miyaura reaction [8] in water.

\section{Experimental}

2.1. General Procedures. All nonaqueous reactions were conducted under an atmosphere of nitrogen with magnetic stirring. Tetrahydrofuran (THF), dichloromethane $\left(\mathrm{CH}_{2} \mathrm{Cl}_{2}\right)$, acetonitrile $(\mathrm{MeCN})$, and diethyl ether $\left(\mathrm{Et}_{2} \mathrm{O}\right)$ were dried by distillation and stored over activated molecular sieves. Dehydrated methanol $(\mathrm{MeOH})$ was purchased from Kanto Chemical (Tokyo, Japan). Dimethyl sulfoxide (DMSO) was purchased from Wako Pure Chemical Industries (Osaka, Japan). All reagents were obtained from commercial suppliers and used without further purification unless otherwise stated. Analytical thin layer chromatography (TLC) was performed on silica gel $60 \mathrm{~F}_{254}$ plates produced by Merck. Column chromatography was performed with acidic Silica gel 60 (spherical, 40-50 $\mathrm{m}$ ) or neutral Silica gel $60 \mathrm{~N}$ (spherical, $40-50 \mu \mathrm{m})$ produced by Kanto Chemical.

Melting point was measured by an AS one ATM-01 apparatus. Infrared (IR) spectra were recorded on a JASCO FT-IR 4100 spectrometer and are reported in wavenumbers $\left(\mathrm{cm}^{-1}\right)$. 


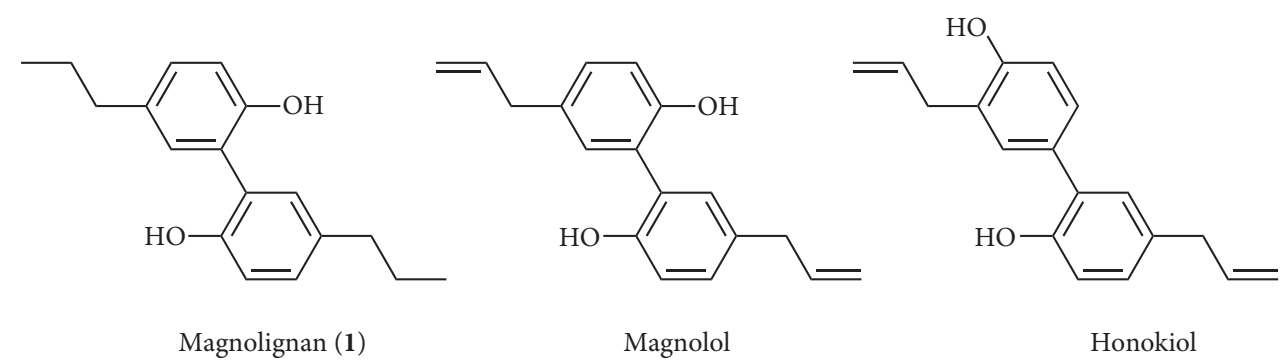

FIGURE 1: Structures of magnolignan (1), magnolol, and honokiol.

${ }^{1} \mathrm{H}$ and ${ }^{13} \mathrm{C}$ NMR spectra were recorded on a JEOL JNMEXC 300 spectrometer $(300 \mathrm{MHz})$ or on a JEOL JNM-ECA 500 spectrometer $(500 \mathrm{MHz}) .{ }^{1} \mathrm{H}$ NMR data are reported as follows: chemical shift $(\delta, \mathrm{ppm})$, integration, multiplicity (s, singlet; $\mathrm{d}$, doublet; $\mathrm{t}$, triplet; $\mathrm{m}$, multiplet), coupling constants $(J)$ in $\mathrm{Hz}$, and assignments. ${ }^{13} \mathrm{C}$ NMR data are reported in terms of chemical shift ( $\delta$, ppm). EI-LRMS (GC-MS) spectra were recorded on a Shimadzu GCMS QP-5050 instrument. EI-HRMS spectra were recorded on a JEOL JMS-700 instrument.

2.2. 1-Methoxy-4-Propylbenzene (3). To a suspension of $10 \%$ $\mathrm{Pd} / \mathrm{C}(0.101 \mathrm{~g})$ in $\mathrm{MeOH}(30 \mathrm{~mL})$ under atmosphere of hydrogen was added 1-methoxy-4-(1-propenyl)benzene 2 $(1.00 \mathrm{~g}, 6.75 \mathrm{mmol})$. After stirring for $3 \mathrm{~h}$ at room temperature, the reaction mixture was filtered through a pad of Celite with $\mathrm{MeOH}$. Concentration in vacuo afforded $3(0.957 \mathrm{~g}$, $6.37 \mathrm{mmol}, 94 \%$ ) as a colorless oil; $R_{f} 0.48$ (hexane/EtOAc = $20: 1$ ); IR (neat) $v_{\max } 2947,2063,1879,1610,1509,1456$, $1248,1179,1110,1038,821,748,699,553 \mathrm{~cm}^{-1}$; ${ }^{1} \mathrm{H}$ NMR $\left(300 \mathrm{MHz}, \mathrm{CDCl}_{3}\right) \delta 7.10(2 \mathrm{H}, \mathrm{d}, J=8.5 \mathrm{~Hz}, \mathrm{ArH}), 6.83$ $(2 \mathrm{H}, \mathrm{d}, J=8.6 \mathrm{~Hz}, \mathrm{ArH}), 3.87(3 \mathrm{H}, \mathrm{s}, \mathrm{OMe}), 2.51(2 \mathrm{H}, \mathrm{t}, J=$ $\left.7.4 \mathrm{~Hz}, \mathrm{CH}_{2}\right), 1.54-1.64\left(2 \mathrm{H}, \mathrm{m}, \mathrm{CH}_{2}\right), 0.92(3 \mathrm{H}, \mathrm{t}, J=7.4 \mathrm{~Hz}$, $\left.\mathrm{CH}_{3}\right) ;{ }^{13} \mathrm{C}$ NMR $\left(75 \mathrm{MHz}, \mathrm{CDCl}_{3}\right) \delta 157.8,134.9,129.4$, 113.7, 55.3, 37.2, 24.9, 13.9; GC-MS $(m / z)$ calcd for $\mathrm{C}_{10} \mathrm{H}_{14} \mathrm{O}$ $[\mathrm{M}]^{+} 150.10$, found 150.05 .

2.3. 2-Bromo-1-Methoxy-4-Propylbenzene (4). To a solution of $N$-bromosuccinimide $(0.498 \mathrm{~g}, 2.80 \mathrm{mmol}, 1.2 \mathrm{eq})$ in $\mathrm{MeCN}(8.75 \mathrm{~mL})$ was added 1-methoxy-4-propylbenzene 3 $(0.351 \mathrm{~g}, 2.34 \mathrm{mmol}, 1.0 \mathrm{eq})$. After stirring for $3 \mathrm{~h}$ at room temperature, the reaction mixture was concentrated in vacuo, and washed with $\mathrm{CCl}_{4}$. Concentration in vacuo afforded 4 (0.521 g, $2.27 \mathrm{mmol}, 97 \%)$ as a colorless oil; $R_{f} 0.61$ (hexane/ EtOAc $=20: 1$ ); IR (neat) $v_{\max } 2957,1602,1495,1262,1187$, $1150,1054,887,808,747,714,672,595,556 \mathrm{~cm}^{-1} ;{ }^{1} \mathrm{H}$ NMR $\left(300 \mathrm{MHz}, \mathrm{CDCl}_{3}\right) \delta 7.36(1 \mathrm{H}, \mathrm{d}, J=2.1 \mathrm{~Hz}, \mathrm{ArH}), 7.06(1 \mathrm{H}$, $\mathrm{dd}, J=8.3,2.1 \mathrm{~Hz}, \mathrm{ArH}), 6.81(1 \mathrm{H}, \mathrm{d}, J=8.3 \mathrm{~Hz}, \mathrm{ArH}), 3.87$ $(3 \mathrm{H}, \mathrm{s}, \mathrm{OMe}), 2.51\left(2 \mathrm{H}, \mathrm{t}, J=7.4 \mathrm{~Hz}, \mathrm{CH}_{2}\right), 1.54-1.64(2 \mathrm{H}$, $\left.\mathrm{m}, \mathrm{CH}_{2}\right), 0.92\left(3 \mathrm{H}, \mathrm{t}, J=7.4 \mathrm{~Hz}, \mathrm{CH}_{3}\right) ;{ }^{13} \mathrm{C} \mathrm{NMR}(75 \mathrm{MHz}$, $\left.\mathrm{CDCl}_{3}\right) \delta 153.9,136.4,133.2,128.4,111.9,111.4,56.3,36.8$, 24.6, 13.7; GC-MS $(m / z)$ calcd for $\mathrm{C}_{10} \mathrm{H}_{13} \mathrm{BrO}[\mathrm{M}]^{+}$228.01, found 227.95; EI-HRMS $(\mathrm{m} / z)$ calcd for $\mathrm{C}_{10} \mathrm{H}_{12} \mathrm{BrO}[\mathrm{M}-\mathrm{H}]^{-}$ 227.0072, found 227.0072.
2.4. 1-Methoxy-4-Propyl-2-(4,4,5,5-Tetramethyl-[1,3,2]Dioxaborolan-2-yl)Benzene (5). To a mixture of $\left[1,1^{\prime}\right.$ bis(diphenylphosphino)ferrocene]palladium(II) dichloride ( $47.7 \mathrm{mg}, \quad 0.0655 \mathrm{mmol}, 5 \mathrm{~mol} \%$ ), bis(pinacolato)diboron (399 $\mathrm{mg}, 1.57 \mathrm{mmol}, 1.2 \mathrm{eq}$ ), and potassium acetate $(386 \mathrm{mg}$, $3.93 \mathrm{mmol}, 3.0 \mathrm{eq})$ was added 2-bromo-1-methoxy-4-propylbenzene 4 (300 $\mathrm{mg}, 1.31 \mathrm{mmol}, 1.0 \mathrm{eq})$ in DMSO $(4.5 \mathrm{~mL})$. After stirring for $24 \mathrm{~h}$ at $80^{\circ} \mathrm{C}$, the reaction mixture was diluted with toluene and quenched with $\mathrm{H}_{2} \mathrm{O}$. The aqueous layer was then extracted with toluene. The combined organic layers were washed with $\mathrm{H}_{2} \mathrm{O}$, dried over $\mathrm{Na}_{2} \mathrm{SO}_{4}$, and concentrated in vacuo. Purification by silica gel column chromatography (hexane/EtOAc $=20: 1$ ) afforded 5 (110.3 mg, $0.399 \mathrm{mmol}, 31 \%), 6(17.0 \mathrm{mg}, 0.0616 \mathrm{mmol}$, $5 \%)$, and $4(69.3 \mathrm{mg}, 0.303 \mathrm{mmol}, 23 \%) .5$ was obtained as a brown oil; $R_{f} 0.4$ (hexane/EtOAc $=5: 1$ ); IR (neat) $v_{\max } 3517$, 2967, 1736, 1602, 1348, 1148, 1037, 963, 915, 853, 819, 752, 676, $581 \mathrm{~cm}^{-1} ;{ }^{1} \mathrm{H}$ NMR $\left(300 \mathrm{MHz}, \mathrm{CDCl}_{3}\right) \delta 7.47(1 \mathrm{H}, \mathrm{d}$, $J=2.2 \mathrm{~Hz}, \mathrm{ArH}), 7.19(1 \mathrm{H}, \mathrm{dd}, J=8.3,2.4 \mathrm{~Hz}, \mathrm{ArH}), 6.78$ $(1 \mathrm{H}, \mathrm{d}, J=8.5 \mathrm{~Hz}, \mathrm{ArH}), 3.80(3 \mathrm{H}, \mathrm{s}, \mathrm{OMe}), 2.52(2 \mathrm{H}, \mathrm{t}$, $\left.J=7.4 \mathrm{~Hz}, \mathrm{CH}_{2}\right), 1.55-1.64\left(2 \mathrm{H}, \mathrm{m}, \mathrm{CH}_{2}\right), 1.35(12 \mathrm{H}, \mathrm{s}$, Bpin), $0.92\left(3 \mathrm{H}, \mathrm{t}, J=7.4 \mathrm{~Hz}, \mathrm{CH}_{3}\right) ;{ }^{13} \mathrm{C}$ NMR $(75 \mathrm{MHz}$, $\left.\mathrm{CDCl}_{3}\right) \delta 162.5,136.8,136.7,132.4,110.5,83.5,56.0,55.6$, 37.1, 24.9, 13.9; GC-MS $(\mathrm{m} / z)$ calcd for $\mathrm{C}_{16} \mathrm{H}_{25} \mathrm{BO}_{3}[\mathrm{M}]^{+}$ 276.18, found 275.95; EI-HRMS $(\mathrm{m} / z)$ calcd for $\mathrm{C}_{16} \mathrm{H}_{25} \mathrm{BO}_{3}$ $[\mathrm{M}]^{+}$276.1897, found 276.1895 .

2.5. 2,2'-Dimethoxy-5,5'-Dipropyl-Biphenyl (6). To a mixture of 2-bromo-1-methoxy-4-propylbenzene $4(41.3 \mathrm{mg}$, $0.180 \mathrm{mmol}, \quad 1.0 \mathrm{eq}), \quad 1$-methoxy-4-propyl-2-(4,4,5,5-tetramethyl-[1,3,2]dioxaborolan-2-yl)benzene $\mathbf{5} \quad(49.6 \mathrm{mg}$, $0.180 \mathrm{mmol}, \quad 1.0 \mathrm{eq}$ ), and tetrakis(triphenylphosphine) palladium(0) $(10.4 \mathrm{mg}, 9.00 \mu \mathrm{moL}, 5 \mathrm{~mol} \%)$ was added potassium carbonate $(74.6 \mathrm{mg}, 0.54 \mathrm{mmol}, 3.0 \mathrm{eq})$ in THF $(2.0 \mathrm{~mL})$. After stirring for $8 \mathrm{~h}$ at reflux, the reaction mixture was concentrated in vacuo and extracted with $\mathrm{CH}_{2} \mathrm{Cl}_{2}$. The combined organic layers were washed with $\mathrm{H}_{2} \mathrm{O}$, dried over $\mathrm{Na}_{2} \mathrm{SO}_{4}$, and concentrated in vacuo. Purification by silica gel column chromatography (hexane/EtOAc $=20: 1$ ) afforded $6(7.7 \mathrm{mg}, 0.0258 \mathrm{mmol}, 14 \%)$ as a yellow oil; $R_{f}$ 0.38 (hexane/EtOAc $=10: 1$ ); IR (neat) $v_{\max } 2955,2052$, $1727,1605,1497,1244,1175,1141,1037,893,809,757$, $634,511 \mathrm{~cm}^{-1} ;{ }^{1} \mathrm{H}$ NMR $\left(300 \mathrm{MHz}, \mathrm{CDCl}_{3}\right) \delta 7.11(2 \mathrm{H}, \mathrm{dd}$, $J=8.3,2.3 \mathrm{~Hz}, \mathrm{ArH}), 7.06(2 \mathrm{H}, \mathrm{d}, J=2.3 \mathrm{~Hz}, \operatorname{ArH}), 6.88$ $(2 \mathrm{H}, \mathrm{d}, J=8.3 \mathrm{~Hz}, \mathrm{ArH}), 3.74(6 \mathrm{H}, \mathrm{s}, \mathrm{OMe}), 2.55(4 \mathrm{H}, \mathrm{t}, J=$ 
$\left.7.5 \mathrm{~Hz}, \mathrm{CH}_{2}\right), 1.57-1.70\left(4 \mathrm{H}, \mathrm{m}, \mathrm{CH}_{2}\right), 0.95(6 \mathrm{H}, \mathrm{t}, J=$ $\left.7.1 \mathrm{~Hz}, \mathrm{CH}_{3}\right) ;{ }^{13} \mathrm{C}$ NMR $\left(75 \mathrm{MHz}, \mathrm{CDCl}_{3}\right) \delta 155.2,134.5$, 131.7, 128.3, 127.8, 111.1, 56.0, 37.3, 24.8, 14.0; GC-MS ( $\mathrm{m} / \mathrm{z})$ calcd for $\mathrm{C}_{20} \mathrm{H}_{26} \mathrm{O}_{2}[\mathrm{M}]^{+}$298.19, found 298.20; EI-HRMS $(\mathrm{m} / z)$ calcd for $\mathrm{C}_{20} \mathrm{H}_{26} \mathrm{O}_{2}[\mathrm{M}]^{+}$298.1933, found 298.1930.

2.6. 2-Methoxy-5-Propylphenylboronic Acid (7). To a solution of 2-bromo-1-methoxy-4-propylbenzene $4(200 \mathrm{mg}$, $0.873 \mathrm{mmol}, 1.0 \mathrm{eq})$ in THF $(3.6 \mathrm{~mL})$ was added $1.6 \mathrm{M} n$ BuLi in hexane $(0.709 \mathrm{~mL}, 1.135 \mathrm{mmol}, 1.3 \mathrm{eq})$ at $-78^{\circ} \mathrm{C}$. After stirring for $5 \mathrm{~min}$, triisopropyl borate $(0.586 \mathrm{~mL}$, $2.619 \mathrm{mmol}, 3.0 \mathrm{eq}$ ) was added at $-78^{\circ} \mathrm{C}$ and the mixture was allowed to warm up to room temperature. After stirring for $13 \mathrm{~h}$ at room temperature, the reaction mixture was acidified with $10 \% \mathrm{HCl}$ aq. and extracted with EtOAc. The combined organic layers were washed with $\mathrm{H}_{2} \mathrm{O}$, dried over $\mathrm{Na}_{2} \mathrm{SO}_{4}$, and concentrated in vacuo. Purification by silica gel column chromatography (hexane/EtOAc $=13: 1$ ) afforded 7 (114.6 mg, $0.591 \mathrm{mmol}, 68 \%)$ and $3(23.6 \mathrm{mg}, 0.157 \mathrm{mmol}$, 18\%). 7 was obtained as a colorless powder; $R_{f} 0.33$ (hexane/EtOAc $=3: 1) ; \mathrm{mp} 71^{\circ} \mathrm{C}$; IR $(\mathrm{KBr}) v_{\max } 3801,3358,2926$, $2355,1607,1415,1338,1229,1155,1097,1043,788,679$, $555 \mathrm{~cm}^{-1}$; ${ }^{1} \mathrm{H}$ NMR $\left(300 \mathrm{MHz}, \mathrm{CDCl}_{3}\right) \delta 7.64(1 \mathrm{H}, \mathrm{d}, J=$ $2.3 \mathrm{~Hz}, \mathrm{ArH}), 7.23(1 \mathrm{H}, \mathrm{d}, J=2.3 \mathrm{~Hz}, \operatorname{ArH}), 6.84(1 \mathrm{H}, \mathrm{d}$, $J=8.4 \mathrm{~Hz}, \mathrm{ArH}), 3.89(3 \mathrm{H}, \mathrm{s}, \mathrm{OMe}), 2.55(2 \mathrm{H}, \mathrm{t}, J=7.1 \mathrm{~Hz}$, $\left.\mathrm{CH}_{2}\right), 1.56-1.68\left(2 \mathrm{H}, \mathrm{m}, \mathrm{CH}_{2}\right), 0.93\left(3 \mathrm{H}, \mathrm{t}, J=7.1 \mathrm{~Hz}, \mathrm{CH}_{3}\right)$; ${ }^{13} \mathrm{C}$ NMR $\left(75 \mathrm{MHz}, \mathrm{CDCl}_{3}\right) \delta 162.8,136.8,135.3,132.8$, 109.9, 77.3, 55.6, 37.1, 24.9, 13.9; EI-HRMS $(\mathrm{m} / \mathrm{z})$ calcd for $\mathrm{C}_{10} \mathrm{H}_{15} \mathrm{BO}_{3}[\mathrm{M}]^{+}$194.1114, found 194.1095.

2.7. 2,2'-Dimethoxy-5,5'-Dipropyl-Biphenyl (6). To a mixture of 2-bromo-1-methoxy-4-propylbenzene 4 (50.5 mg, $0.220 \mathrm{mmol}, 1.0 \mathrm{eq}$ ) and 2-methoxy-5-propylphenylboronic acid $7(55.4 \mathrm{mg}, 0.287 \mathrm{mmol}, 1.3 \mathrm{eq})$ were added palladium(II) acetate $(0.01 \mathrm{mg}, 0.437 \mu \mathrm{moL}, 0.2 \mathrm{~mol} \%)$, potassium carbonate $(75.0 \mathrm{mg}, 0.546 \mathrm{mmol}, 2.5 \mathrm{eq})$, and tetrabutylammonium bromide $\left(70.0 \mathrm{mg}, 0.218 \mathrm{mmol}, 1.0\right.$ eq) in $\mathrm{H}_{2} \mathrm{O}$ $(0.23 \mathrm{~mL})$. The reaction mixture was degassed by freeze/ pump/thaw techniques. After stirring for $2 \mathrm{~h}$ at $70^{\circ} \mathrm{C}$, the reaction mixture was cooled to room temperature, diluted with $\mathrm{H}_{2} \mathrm{O}$, and then extracted with EtOAc. The combined organic layers were washed with $\mathrm{H}_{2} \mathrm{O}$, dried over $\mathrm{Na}_{2} \mathrm{SO}_{4}$, and concentrated in vacuo. Purification by silica gel column chromatography (hexane/EtOAc $=80: 1$ ) afforded 6 (63.7 mg, $0.213 \mathrm{mmol}, 98 \%$ ).

2.8. 2,2'-Dihydroxy-5,5'-Dipropyl-Biphenyl (1). To a solution of $2,2^{\prime}$-dimethoxy-5, $5^{\prime}$-dipropyl-biphenyl $6(24.2 \mathrm{mg}$, $0.081 \mathrm{mmol}, 1.0 \mathrm{eq})$ in $\mathrm{CH}_{2} \mathrm{Cl}_{2}(1.4 \mathrm{~mL})$ was added $1 \mathrm{M}$ boron tribromide in $\mathrm{CH}_{2} \mathrm{Cl}_{2}(0.406 \mathrm{~mL}, 0.406 \mathrm{mmol}, 5.0 \mathrm{eq})$ at $-78^{\circ} \mathrm{C}$, then allowed to warm up to room temperature. After stirring for $1.5 \mathrm{~h}$, the reaction mixture was quenched carefully with $10 \% \mathrm{HCl}$ aq. at $0^{\circ} \mathrm{C}$ and extracted with $\mathrm{Et}_{2} \mathrm{O}$. The combined organic layers were washed with $\mathrm{H}_{2} \mathrm{O}$, dried over $\mathrm{Na}_{2} \mathrm{SO}_{4}$, and concentrated in vacuo. Purification by silica gel column chromatography (hexane/EtOAc $=20: 1$ ) afforded 1 (18.3 $\mathrm{mg}, 0.068 \mathrm{mmol}, 83 \%)$ as a colorless powder;
$R_{f} 0.43$ (hexane/EtOAc $=3: 1$ ); mp $144^{\circ} \mathrm{C}$; IR $(\mathrm{KBr}) v_{\text {max }}$ 3206, 2963, 2923, 2855, 1494, 1415, 1226, 1113, 887, 818, 797, $598,534,436 \mathrm{~cm}^{-1} ;{ }^{1} \mathrm{H}$ NMR $\left(500 \mathrm{MHz}, \mathrm{CDCl}_{3}\right) \delta 7.13(2 \mathrm{H}$, dd, $J=8.0,2.3 \mathrm{~Hz}, \mathrm{ArH}), 7.06(2 \mathrm{H}, \mathrm{d}, J=2.3 \mathrm{~Hz}, \mathrm{ArH})$, $6.95(2 \mathrm{H}, \mathrm{d}, J=8.0 \mathrm{~Hz}, \mathrm{ArH}), 2.57\left(4 \mathrm{H}, \mathrm{t}, J=7.5 \mathrm{~Hz}, \mathrm{CH}_{2}\right)$, $1.60-1.67\left(4 \mathrm{H}, \mathrm{m}, \mathrm{CH}_{2}\right), 0.95\left(6 \mathrm{H}, \mathrm{t}, J=7.5 \mathrm{~Hz}, \mathrm{CH}_{3}\right) ;{ }^{13} \mathrm{C}$ NMR $\left(125 \mathrm{MHz}, \mathrm{CDCl}_{3}\right) \delta 151.0,136.0,131.1,130.0,123.4$, 116.5, 37.3, 24.9, 14.0; EI-HRMS $(m / z)$ calcd for $\mathrm{C}_{18} \mathrm{H}_{22} \mathrm{O}_{2}$ $[\mathrm{M}]^{+} 270.1620$, found 270.1613 .

\section{Results and Discussion}

Starting with commercially available trans-anethole (2), the synthesis of $\mathbf{1}$ involved hydrogenation, bromination, boronation, Suzuki-Miyaura reaction, and demethylation, as illustrated in Scheme 1. Initially, direct bromination of 2 using $N$ bromosuccinimide (NBS) was intended as the first step in the synthesis. However, this reaction did not proceed. Therefore, alkene 2 was reduced by $\mathrm{H}_{2}$ with $\mathrm{Pd} / \mathrm{C}$ to gave alkane 3 in $94 \%$ yield [9]. Obtained $\mathbf{3}$ was then converted to bromide $\mathbf{4}$ in good yield (70-80\%, data not shown) using NBS and $\mathrm{HBF}_{4} / \mathrm{Et}_{2} \mathrm{O}$ in $\mathrm{MeCN}$ at $-20^{\circ} \mathrm{C}$ to room temperature [10]. However, the product was a mixture of monobromide $\mathbf{4}$ and the dibromide compound. It was thought that acidic condition prompted the reactivity of the bromination. Therefore, the reaction was attempted with 1.2 equivalents of NBS without additives in $\mathrm{MeCN}$ at room temperature. The desired compound $\mathbf{4}$ was obtained as a single product in $97 \%$ yield [11].

Next, the transformation of bromide $\mathbf{4}$ into arylboronate ester 5 was pursued. Unfortunately, in a one pot reaction using (Bpin) $)_{2}$ in the presence of $5 \mathrm{~mol} \% \mathrm{PdCl}_{2}$ (dppf) and AcOK in DMSO at $80^{\circ} \mathrm{C}$, compound 5 was obtained in only $31 \%$ yield along with biaryl compound $\mathbf{6}$ in 5\% yield and recovered starting material 4 in $23 \%$ yield [12]. Although the yield for compound $\mathbf{6}$ could not be improved in this reaction, biaryl product 6 was synthesized in 14\% yield through a Suzuki-Miyaura cross-coupling reaction between $\mathbf{4}$ and $\mathbf{5}$ in the presence of $5 \mathrm{~mol} \% \mathrm{Pd}\left(\mathrm{PPh}_{3}\right)_{4}$ and $\mathrm{K}_{2} \mathrm{CO}_{3}$ in THF under reflux condition [13].

As an alternative strategy, arylboronic acid 7 was prepared from bromide $\mathbf{4}$ as a precursor for the Suzuki-Miyaura reaction (Scheme 1). Bromide 4 was thus converted into 7 with $n$-BuLi and triisopropyl borate in $68 \%$ yield, with alkane 3 as a by-product in $18 \%$ yield [14]. The Suzuki-Miyaura cross-coupling reaction between 4 and 7 then afforded biaryl product 6 in $98 \%$ yield using $0.2 \mathrm{~mol} \% \mathrm{Pd}(\mathrm{OAc})_{2}$ in $\mathrm{H}_{2} \mathrm{O}$ at $70^{\circ} \mathrm{C}$ in the presence of one equivalent of tetrabutylammonium bromide (TBAB) as a phase transfer catalyst [15]. This reaction was achieved as an eco-friendly system with a high yield. Finally, removal of the methyl group from $\mathbf{6}$ using $\mathrm{BBr}_{3}$ in $\mathrm{CH}_{2} \mathrm{Cl}_{2}$ at $-78^{\circ} \mathrm{C}$ to room temperature gave the desired magnolignan $\mathbf{1}$ in $83 \%$ yield [16]. Synthetic $\mathbf{1}$ was fully assigned by spectroscopic analysis, including ${ }^{1} \mathrm{H}$ NMR, ${ }^{13} \mathrm{C}$ NMR, IR, and EI-HRMS [3].

In conclusion, the total synthesis of magnolignan 1, a new skin lightening component for use in cosmetics, was achieved in five steps with overall $50 \%$ yield. An aqueous Suzuki-Miyaura reaction was the key step in the synthesis. 


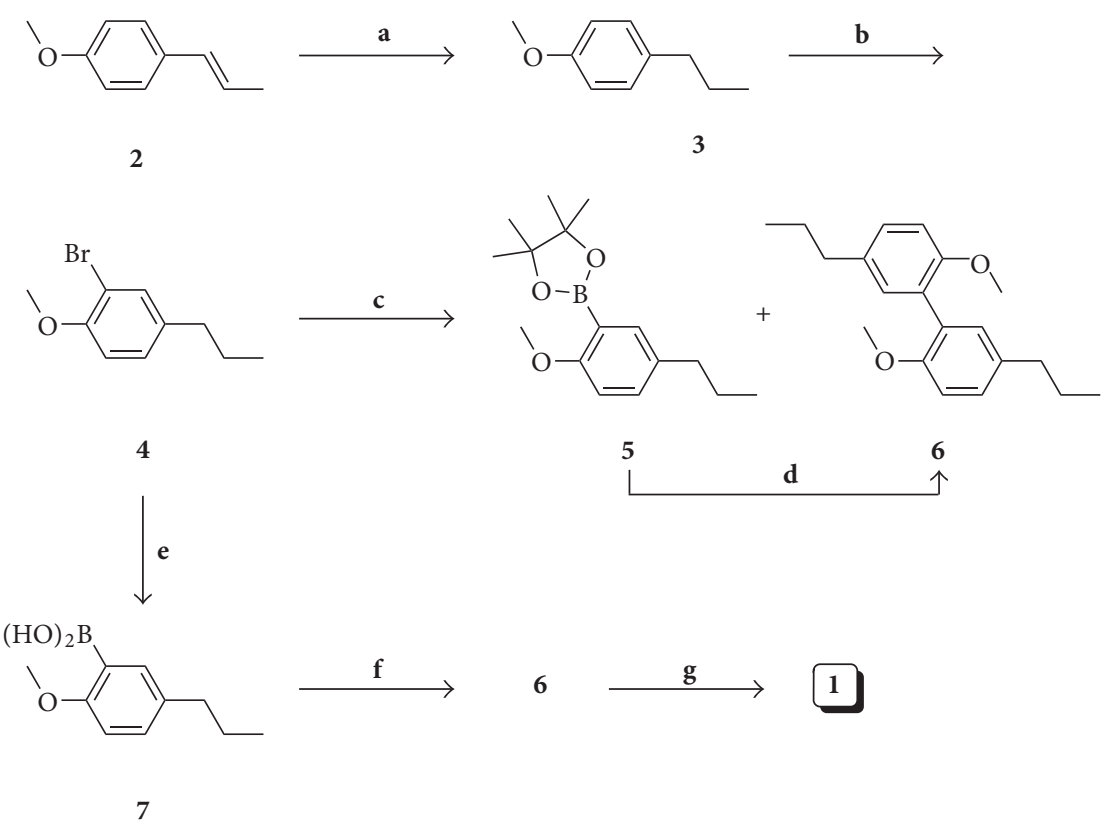

Scheme 1: Total synthesis of $\mathbf{1}$. Reagents and conditions: (a) $\mathrm{H}_{2}, 10 \%$ (w/w) Pd/C, $\mathrm{MeOH}, \mathrm{rt}, 3 \mathrm{~h}, 94 \%$; (b) NBS, $\mathrm{MeCN}^{\mathrm{rt}}, 3 \mathrm{~h}, \mathrm{CCl}$, $97 \%$; (c) $\mathrm{PdCl}_{2}$ (dppf), (Bpin) $)_{2}$, AcOK, DMSO, $80^{\circ} \mathrm{C}, 24 \mathrm{~h}, 31 \%$ (5), 5\% (6), 23\% (4); (d) 4, $\mathrm{Pd}\left(\mathrm{PPh}_{3}\right)_{4}, \mathrm{~K}_{2} \mathrm{CO}_{3}, \mathrm{THF}, \mathrm{reflux}, 8 \mathrm{~h}, 14 \%$; (e) $n$-BuLi, $\mathrm{B}(\mathrm{O} i \mathrm{Pr})_{3}, \mathrm{THF},-78^{\circ} \mathrm{C}$ to rt, $13 \mathrm{~h}, 68 \%$ (7), $18 \%$ (3); (f) $4, \mathrm{Pd}(\mathrm{OAc})_{2}, \mathrm{~K}_{2} \mathrm{CO}_{3}, \mathrm{TBAB}, \mathrm{H}_{2} \mathrm{O}, 70^{\circ} \mathrm{C}, 2 \mathrm{~h}, 98 \% ;(\mathbf{g}) \mathrm{BBr}_{3}, \mathrm{CH}_{2} \mathrm{Cl}_{2},-78^{\circ} \mathrm{C}$ to rt, $1.5 \mathrm{~h}$, $83 \%$.

The palladium-catalyzed Suzuki-Miyaura reaction in $\mathrm{H}_{2} \mathrm{O}$ was achieved with excellent yield, and can be considered an eco-friendly reaction. Through variation of the SuzukiMiyaura coupling precursors, this synthetic strategy is well suited for the preparation of a wide range of magnolignan derivatives for use in further SAR studies.

\section{Acknowledgments}

The authors are grateful to Ms. Yasuko Shimizu, Sophia University, for measurement of the high-resolution mass spectra, and to Ms. Emiko Okano, Sophia University, for measurement of the NMR spectra $(500 \mathrm{MHz})$.

\section{References}

[1] Z.-M. Hu, Q. Zhou, T.-C. Lei, S.-F. Ding, and S.-Z. Xu, "Effects of hydroquinone and its glucoside derivatives on melanogenesis and antioxidation: biosafety as skin whitening agents," Journal of Dermatological Science, vol. 55, no. 3, pp. 179-184, 2009.

[2] K. Nakamura, M. Yoshida, H. Uchiwa, Y. Kawa, and M. Mizoguchi, "Down-regulation of melanin synthesis by a biphenyl derivative and its mechanism," Pigment Cell Research, vol. 16, no. 5, pp. 494-500, 2003.

[3] Z.-L. Kong, S.-C. Tzeng, and Y.-C. Liu, "Cytotoxic neolignans: an SAR study," Bioorganic and Medicinal Chemistry Letters, vol. 15, no. 1, pp. 163-166, 2005.

[4] G. Imokawa, Y. Yada, and M. Okuda, "Allergic contact dermatitis releases soluble factors that stimulate melanogenesis through activation of protein Kinase C-related signal-transduction pathway," Journal of Investigative Dermatology, vol. 99, no. 4, pp. 482-488, 1992.
[5] H. P. Seymour, "Separation, purification, and properties of two tyrosinases from hamster melanoma," The Journal of Biological Chemistry, vol. 238, pp. 2351-2357, 1963.

[6] H. Ando, Y. Funasaka, M. Oka et al., "Possible involvement of proteolytic degradation of tyrosinase in the regulatory effect of fatty acids on melanogenesis," Journal of Lipid Research, vol. 40, no. 7, pp. 1312-1316, 1999.

[7] G. Sartori, R. Maggi, F. Bigi et al., "Oxidative coupling of dichloroaluminium phenolates: highly selective synthesis of hydroxylated bi- and tetraaryls," Tetrahedron, vol. 48, no. 43, pp. 9483-9494, 1992.

[8] N. Miyaura and A. Suzuki, "Palladium-catalyzed cross-coupling reactions of organoboron compounds," Chemical Reviews, vol. 95, no. 7, pp. 2457-2483, 1995.

[9] U. Bora, K. Yaguchi, A. Kume, T. Maegawa, Y. Monguchi, and H. Sajiki, "Temperature-dependent suppression of palladium on carbon-catalyzed hydrogenations," Catalysis Communications, vol. 10, no. 8, pp. 1161-1165, 2009.

[10] T. Oberhauser, "A new bromination method for phenols and anisoles: $\mathrm{NBS} / \mathrm{HBF}_{4} \cdot \mathrm{Et}_{2} \mathrm{O}$ in $\mathrm{CH}_{3} \mathrm{CN}$," The Journal of Organic Chemistry, vol. 62, no. 13, pp. 4504-4506, 1997.

[11] M. C. Carreño, J. L. García Ruano, G. Sanz, M. A. Toledo, and A. Urbano, "N-bromosuccinimide in acetonitrile: a mild and regiospecific nuclear brominating reagent for methoxybenzenes and naphthalenes," The Journal of Organic Chemistry, vol. 60, no. 16, pp. 5328-5331, 1995.

[12] D. C. Gerbino, S. D. Mandolesi, H.-G. Schmalz, and J. C. Podestá, "Introduction of allyl and prenyl side-chains into aromatic systems by Suzuki cross-coupling reactions," European Journal of Organic Chemistry, no. 23, pp. 3964-3972, 2009.

[13] H. Goto, H. Katagiri, Y. Furusho, and E. Yashima, "Oligoresorcinols fold into double helices in water," Journal of the American Chemical Society, vol. 128, no. 22, pp. 7176-7178, 2006. 
[14] M. C. Redond, M. Veguillas, M. Ribagorda, and M. C. Carreño, "Control of the regio- and stereoselectivity in diels-alder reactions with quinone boronic acids," Angewandte Chemie International Edition, vol. 48, no. 2, pp. 370-374, 2009.

[15] D. Badone, M. Baroni, R. Cardamone, A. Ielmini, and U. Guzzi, "Highly efficient palladium-catalyzed boronic acid coupling reactions in water: scope and limitations," The Journal of Organic Chemistry, vol. 62, no. 21, pp. 7170-7173, 1997.

[16] Y.-H. Cho, A. Kina, T. Shimada, and T. Hayashi, "Asymmetric synthesis of axially chiral biaryls by nickel-catalyzed Grignard cross-coupling of dibenzothiophenes," The Journal of Organic Chemistry, vol. 69, no. 11, pp. 3811-3823, 2004. 

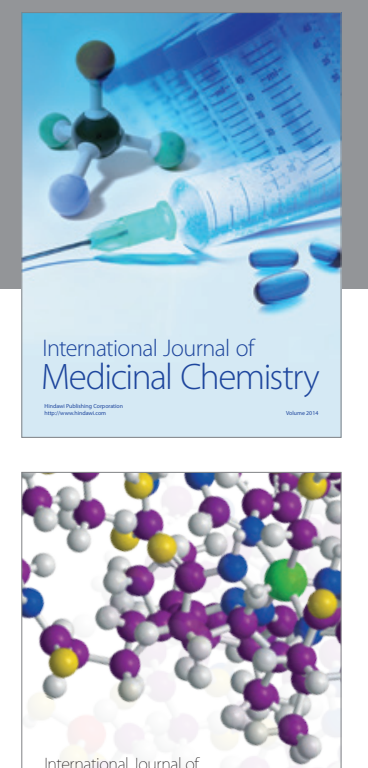

\section{Carbohydrate} Chemistry

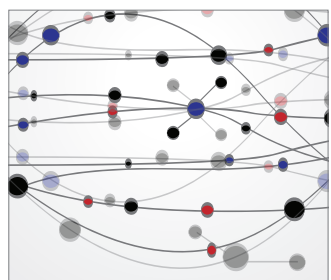

The Scientific World Journal

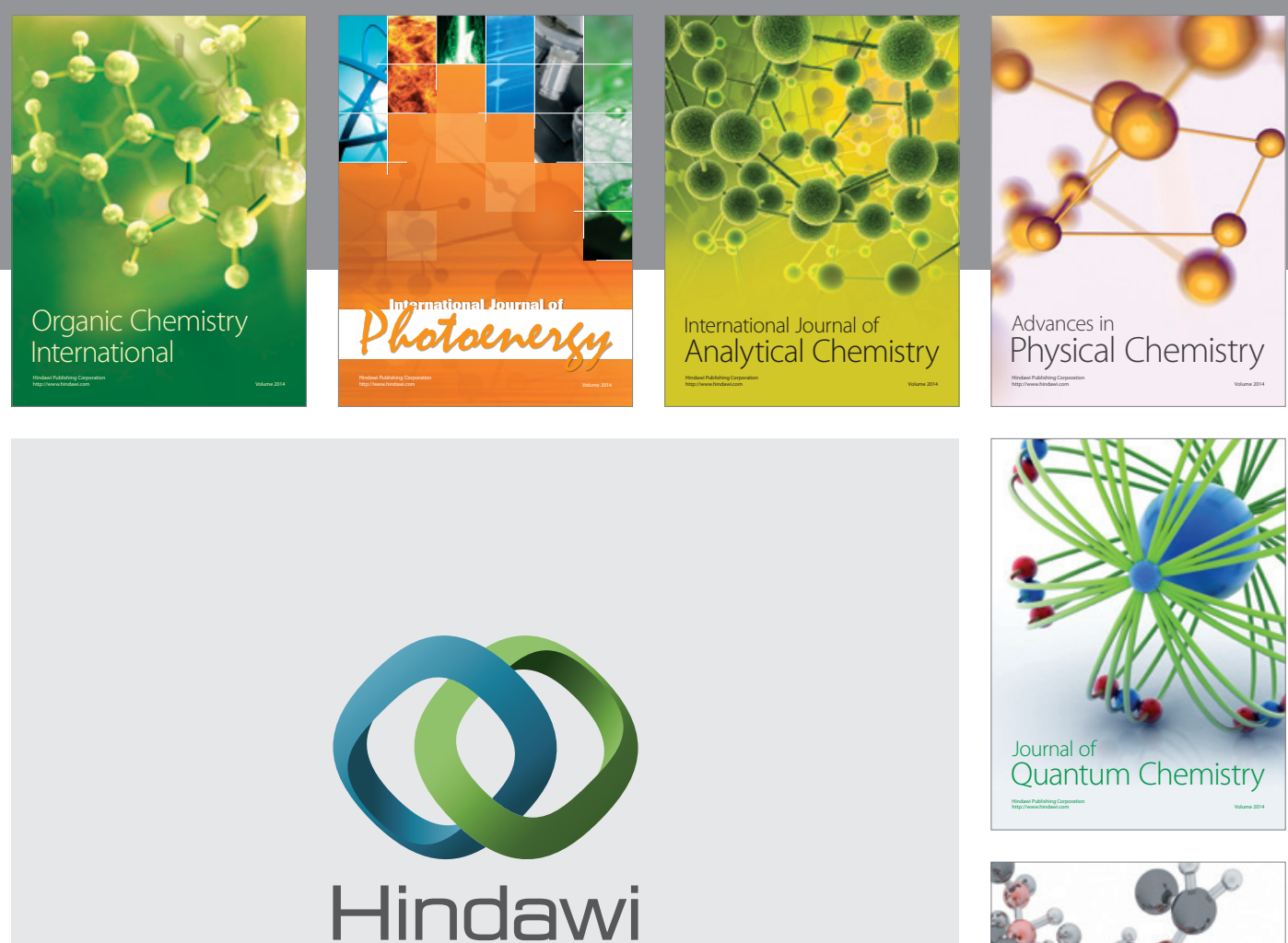

Submit your manuscripts at

http://www.hindawi.com

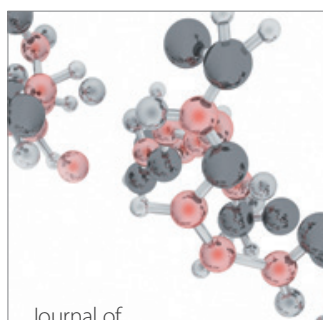

Analytical Methods

in Chemistry

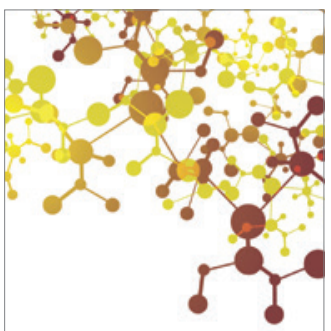

Journal of

Applied Chemistry

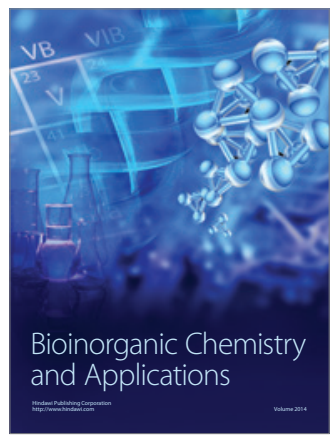

Inorganic Chemistry
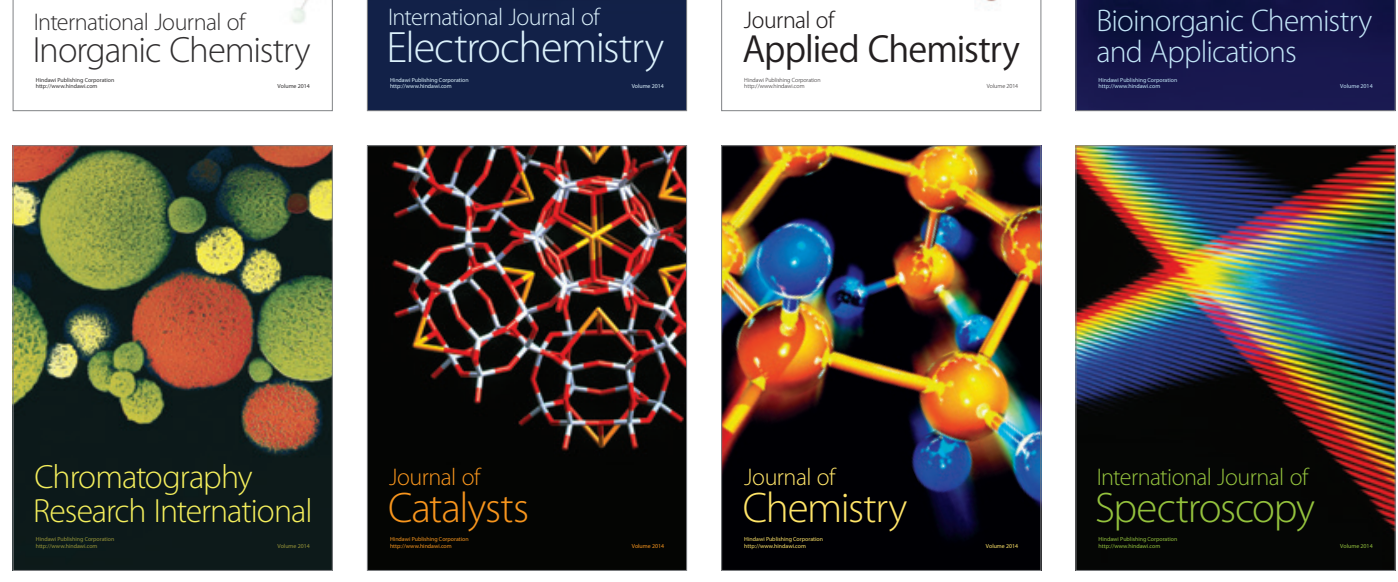